\title{
Adherence characteristics of coagulase-negative staphylococci isolated from patients with infective endocarditis
}

\author{
ROSEMARY G. A. CREE* $\dagger$, I. PHILLIPS $\dagger$ and W. C. NOBLE* $\dagger \ddagger$ \\ * Department of Microbial Diseases, St John's Institute of Dermatology and $\uparrow$ Division of Microbiology, United \\ Medical and Dental Schools, St Thomas' Hospital, London SE1 7EH
}

\begin{abstract}
Summary. Coagulase-negative staphylococci isolated from patients with endocarditis were divided according to whether the infection was of native or of prosthetic valves and was acquired either in the community or in hospital. Comparisons were made with strains from intravenous line-associated bacteraemias. All strains were examined by direct and indirect adherence tests. Line-associated bacteraemia strains were more likely to produce slime and were more hydrophilic but were less likely to attach HEp2 tissue culture cells than were endocarditis strains, and almost equally likely to adhere to plastic and extracellular matrix proteins. Amongst the endocarditis strains, there was little difference in slime production but hospital-acquired or prosthetic-valve strains were more hydrophobic and more likely to adhere to silicone than were the native-valve or community-acquired strains. Exposure of extracellular matrix proteins on native valves due to a pre-existing non-infective heart condition may account for the selection of strains able to adhere to fibronectin or laminin.
\end{abstract}

\section{Introduction}

Coagulase-negative staphylococci (CNS) belonging to the normal human skin flora cause a wide range of hospital-acquired infections with increasing mortality and morbidity. Originally considered to be clinically insignificant contaminants in clinical specimens, in recent years, CNS have become recognised increasingly as important agents of hospital acquired infection..$^{1-4}$ They are essentially opportunists, in that infections are nearly always associated with abnormal circumstances, especially the presence of a "foreign" medical device such as an intravascular catheter or prosthesis.

CNS may be associated with infective endocarditis, a major cause of morbidity and mortality among certain groups of patients. These groups include individuals with a pre-existing cardiac valve lesion (e.g., rheumatic or congenital heart disease), those who have intracardiac prosthetic devices, or those who are intravenous drug abusers. However, for some forms of infective endocarditis, infection may occur in persons with no previous history of cardiac damage or surgery. ${ }^{5}$
One of the key components of pathogenicity is the capacity of an organism to adhere to host tissue. The studies reported here were undertaken to attempt to differentiate between CNS isolates from native and prosthetic valves and between community- and hospital-acquired infections.

\section{Materials and methods}

\section{Organisms}

Type strains Staphylococcus haemolyticus NCTC 11042 and $S$. epidermidis NCTC 11047 were used throughout. $S$. aureus Cowan 1 (NCTC 8530) and $S$. haemolyticus E2498, and S. aureus Wood 46 (NCTC 7121) and S. epidermidis 3380 were used as positive and negative control strains, respectively, for the adherence experiments; $S$. haemolyticus E2498 and $S$. epidermidis 3380 were obtained from the collection at Department of Medical Microbiology, Lund.

A number of CNS isolates from patients with community-acquired (CAE) or hospital-acquired endocarditis (HAE) had been collected over several years and maintained as lyophilised preparations. These strains could be divided into those associated with native-valve (NVE) and with prosthetic-valve endo- 
carditis (PVE). Native valve isolates comprised $75 \%$ of the community-acquired, but only $15 \%$ of the hospital-acquired, strains. The isolates were selected from the collection held in the Microbiology Department, St Thomas' Hospital, London $(n=45)$, or were donated by Dr J. Richardson, Central Public Health Laboratory, Colindale, London $(n=6)$, and by Dr V. Thamdrup Rosdahl, Statens Seruminstitut, Copenhagen, Denmark $(n=45)$. A group of 16 isolates from inpatients with line-associated bacteraemias (LAB) associated with intravenous catheters collected at St Thomas' Hospital, London, were used for comparison.

\section{Strain characteristics}

Organisms were grown at $37^{\circ} \mathrm{C}$ on Blood Agar or Blood Agar Base (Unipath, Basingstoke, Hants), and stored at $4^{\circ} \mathrm{C}$ for up to 6 weeks. Unless otherwise stated, all isolates were cultured on blood agar base and incubated at $37^{\circ} \mathrm{C}$ for $18-20 \mathrm{~h}$ before use. The susceptibility of organisms to antibiotics was tested by the disk diffusion method with disks containing penicillin $10 \mu \mathrm{g}$, tetracycline $30 \mu \mathrm{g}$, erythromycin $15 \mu \mathrm{g}$, clindamycin $2 \mu \mathrm{g}$, gentamicin $10 \mu \mathrm{g}$ or mupirocin $5 \mu \mathrm{g}$. The plates were then incubated at $37^{\circ} \mathrm{C}$ for $18-20 \mathrm{~h}$. All isolates from the St Thomas' Hospital collection were speciated by the ATB 32 Staph Ident system (bioMérieux, Basingstoke). The remaining strains had been speciated in the national reference laboratories that donated them.

The plasmid content of the organisms was determined by a modification of the method of Wilson $e t$ $a l .{ }^{6}$ Briefly, cell walls were digested with lysozyme and lysostaphin, and the resulting protoplasts were lysed gently with Brij-58 to release the plasmid DNA. Purified samples were then precipitated and separated on agarose $0.8 \%$ horizontal slab gels at $30 \mathrm{~V}$ for $18 \mathrm{~h}$ in Tris-borate-EDTA buffer, with Escherichia coli V517 extract as the mol. wt marker.

\section{Cell-protein profiles}

Protein extracts were prepared by a modification of the method of Pierre et al. ${ }^{7}$ Bacteria were suspended in $100 \mu \mathrm{l}$ of Tris- $\mathrm{HCl}(\mathrm{pH} \mathrm{6.8)}$ and $10 \mu \mathrm{l}$ of lysostaphin solution, and incubated at $37^{\circ} \mathrm{C}$ for about $15 \mathrm{~min}$ until digestion was complete. PAGE extraction buffer containing SDS and mercaptoethanol was added and the samples were heated to $95^{\circ}-100^{\circ} \mathrm{C}$ for $5-10 \mathrm{~min}$. Whole cell extracts were then separated in polyacrylamide $10 \%$ gels in a BioRad mini protean II system (BioRad, Hemel Hempstead) at $200 \mathrm{~V}$ for 45-60 min. Low mol. wt standards (Pharmacia, St Albans, Herts) were run simultaneously. Proteins were stained with Coomassie Brilliant Blue R250.

Cell-surface proteins were extracted by a modified lithium chloride method. ${ }^{8}$ Bacteria (c. $1 \mathrm{~g}$ wet weight) were extracted in $1.5 \mathrm{ml}$ of lithium chloride $(\mathrm{pH} 5)$ at $37^{\circ} \mathrm{C}$ overnight. The crude extract was then centrifuged at $42000 \mathrm{rpm}$ at $4^{\circ} \mathrm{C}$ for $60 \mathrm{~min}$ and the supernate was supplemented with phenyl methyl sulphonyl fluoride, and stored at $-20^{\circ} \mathrm{C}$ until run on a gel, under the same conditions as for whole cell extracts.

Immunoblotting of lithium chloride extracts was performed by the method in the Midget multiblot equipment manual (Pharmacia), modified to suit the horseradish peroxidase (HRP) kit obtained from BioRad. Separate antisera were raised in rabbits against strains of $S$. epidermidis and $S$. haemolyticus from patients undergoing continuous ambulatory peritoneal dialysis (CAPD), ${ }^{9}$ and the sera were mixed to produce more discriminatory results. A biotinylated mol. wt marker (BioRad) was used as standard. This was detected with a streptavidin-HRP conjugate added at the same time as the goat anti-rabbit $\operatorname{IgG}(\mathrm{H}+\mathrm{L})$ HRP conjugate used to detect the antigens in the samples.

\section{Measurement of hydrophobicity}

Bacterial cell hydrophobicity was determined by salting out according to the method of Lindahl et al..$^{10}$ Bacterial cells from agar-grown cultures were suspended in phosphate-buffered saline (PBS), $\mathrm{pH} 7 \cdot 2$, and diluted to $10^{8}$ cells $/ \mathrm{ml}$; the suspensions were mixed with equal volumes of ammonium sulphate solutions of varying molarities on glass slides and observed for aggregation at room temperature for $1 \mathrm{~min}$. The lowest molarity at which aggregation occurred was taken to be the numeric hydrophobic value of the isolate. Breakpoints of 0.2 and $1.8 \mathrm{M}$ were designated according to Ljungh et al. ${ }^{11}$ below and above which organisms were classified as hydrophobic and hydrophilic, respectively.

\section{Slime production}

The ability to produce slime was determined by the Congo red agar method.$^{12}$ Each isolate was inoculated on to blood agar base supplemented with Congo red $0.8 \mathrm{~g} / \mathrm{L}$ and sucrose $50 \mathrm{~g} / \mathrm{L}$ and incubated at $37^{\circ} \mathrm{C}$ for $24 \mathrm{~h}$, then left at room temperature for a further $48 \mathrm{~h}$. Slime producers were recognised as black colonies with a dry crystalline consistency. Non-producers appeared pink-white and an intermediate result was indicated by dark pink-red colonies without a dry crystalline consistency.

\section{Adherence to plastics}

Binding to plastic surfaces was investigated by a method based on that of Christensen et al ${ }^{13} \mathrm{~A} \log$ phase culture of the isolate was inoculated into tryptone soya broth in the wells of a polystyrene microtitration tray (Falcon III plate; BectonDickinson) and incubated overnight at $37^{\circ} \mathrm{C}$. The contents of the tray were then discarded and the tray was washed five times with PBS and fixed with formaldehyde $25 \%$ before being stained with crystal 
violet. Results were obtained both visually and spectrophotometrically at $540 \mathrm{~nm}$.

Adherence to silicone rubber was investigated by a modification of the above method. ${ }^{14}$ Briefly, a 5-mm disk of silicone sheeting (Silastic; Dow Corning, Reading, Berks) was cut and placed in the bottom of the well of a microtitration tray. The assay was then performed as above. Results were read by removing the silicone disk, placing it on the lid of the tray and then reading spectrophotometrically by reflectance as well as visually.

\section{Adherence to epithelial cells}

HEp2 cells were grown as a monolayer on the surface of a coverslip. Overnight bacterial growth was removed from the surface of a plate, washed in PBS and resuspended in $10 \mathrm{ml}$ of PBS $\left(c .10^{9}\right.$ cells $\left./ \mathrm{ml}\right)$. The transport medium was removed from the monolayer and $0.5 \mathrm{ml}$ of bacterial suspension was added. The coverslip was then incubated at $37^{\circ} \mathrm{C}$ for $3 \mathrm{~h}$, the fluid was removed and the monolayer was washed three times in PBS and fixed with formaldehyde.

The coverslip was mounted on a glass slide with DPX-mountant and left to dry before Gram's staining. The epithelial cells could then be viewed microscopically and bacterial adherence graded as positive, negative or intermediate by comparison with control cultures.

\section{Binding to lectins}

Fibronectin, vitronectin, laminin or collagen type I were prepared for binding experiments according to the methods of Naidu et al. ${ }^{15}$ Briefly, latex beads $(0.8 \mu \mathrm{m})$ were incubated and shaken with $100 \mu \mathrm{g}$ of matrix protein overnight at $37^{\circ} \mathrm{C}$, then washed and resuspended in thiomersal and albumin to ensure that all available binding sites on the beads were coated, and kept at $4^{\circ} \mathrm{C}$ until used.

Bacteria were harvested and washed in potassium phosphate buffer (pH 6.8) and resuspended to $c .10^{10}$ cell $/ \mathrm{ml}$. The agglutination reaction was performed on glass slides by mixing equal volumes of bacterial suspension and coated beads. Clumping was observed after 2 min and scored as high $(+++$ or ++ ) or low $(+$ or -$)$ by comparison with control cultures. All isolates were tested for auto-agglutination in phosphate buffer. The salt aggregation test and particle agglutination assay have been found to be reproducible by ourselves and others. ${ }^{15-17}$

\section{Chemicals}

Fibronectin was purified from human plasma on gelatin-sepharose ${ }^{18}$ by $\mathrm{Dr}$ E. Jakab (University of Lund, Sweden). Vitrogen $100^{\circledR}$ (collagen type I) was obtained from Collagen Corporation (Palo Alto, CA, USA). Laminin isolated from an Engelbreth-HolmSwarm transplantable mouse tumour ${ }^{19}$ was kindly supplied by $\mathrm{Dr} \mathrm{K}$. Valkonen, University of Oulu, Oulu, Finland. Vitronectin was purified from human plasma on heparin-sepharose ${ }^{20}$ by Dr E. Jakab. Coated PAA beads were kindly prepared by Dr M. Paulsson and donated by Professor T. Wadström, Department of Medical Microbiology, University of Lund, Sweden. Ovalbumin was purchased from Sigma, thiomersal from ICN, latex beads from Difco and blood agar base from Unipath. All chemicals were analytical grade and obtained from Sigma, BDH or Pharmacia unless stated otherwise.

\section{Statistical analysis}

Analysis was by the $\chi^{2}$ test.

\section{Results}

\section{Characteristics of strains}

Staphylococcal species and sources of isolation are shown in table I. On the basis of antibiogram, plasmid profile, source and date of isolation, there were no multiple isolates from any patient although multiple strains were isolated from some patients with successive episodes of endocarditis. There were insufficient strains of species other than $S$. epidermidis to permit separate analysis.

The majority of community-acquired strains were susceptible to all antibiotics tested. Hospital-acquired strains showed a higher frequency of resistance to the antibiotics tested, especially penicillin. Resistant organisms tended to be multi-resistant. When split according to disease types, a moderate percentage of native-valve strains were resistant to penicillin and tetracycline. Many prosthetic-valve strains were resistant to penicillin and tetracycline and more were resistant to erythromycin and clindamycin than in other groups. However, since a majority of prostheticvalve strains were Danish in origin, the increased incidence of resistance to a certain antibiotic may be a reflection of current Danish patterns of resistance. Line-associated bacteraemia strains, which were hospital-acquired, had resistance profiles similar to the hospital-acquired endocarditis strains. The number of fully susceptible isolates was lower in this group.

More of the hospital-associated strains (56\%) contained plasmids compared with communityacquired strains $(28 \%)$. Only $36 \%$ of native-valve strains contained plasmids, compared with $56 \%$ of prosthetic-valve and $69 \%$ of line-associated strains. There was no common sized plasmid which might be related to adherence.

\section{Cell-protein profiles}

The protein profiles of $S$. epidermidis strains from all the groups were indistinguishable, the profiles containing too many bands to be able to differentiate strains below species level (data not shown). Ex- 
Table I. Sources and identities of CNS

\begin{tabular}{|c|c|c|c|c|}
\hline Source & Valve & Origin & Species & Number of isolates \\
\hline \multirow[t]{10}{*}{ Community-acquired } & \multirow[t]{7}{*}{ Native } & \multirow[t]{6}{*}{ STH } & S. epidermidis & 13 \\
\hline & & & S. capitis & 2 \\
\hline & & & S. cohnii & 2 \\
\hline & & & S. haemolyticus & 1 \\
\hline & & & S. hominis & 2 \\
\hline & & & S. lugdunensis & 2 \\
\hline & & DEN & S. epidermidis & 4 \\
\hline & \multirow[t]{3}{*}{ Prosthetic } & \multirow[t]{3}{*}{ STH } & S. epidermidis & 3 \\
\hline & & & S. capitis & 2 \\
\hline & & & S. lugdunensis & 1 \\
\hline \multirow[t]{12}{*}{ Hospital-acquired } & \multirow[t]{6}{*}{ Native } & \multirow[t]{5}{*}{ STH } & S. epidermidis & 9 \\
\hline & & & S. capitis & 1 \\
\hline & & & S. haemolyticus & 1 \\
\hline & & & S. lugdunensis & 1 \\
\hline & & & S. simulans & 1 \\
\hline & & DEN & S. epidermidis & 8 \\
\hline & \multirow[t]{6}{*}{ Prosthetic } & \multirow[t]{2}{*}{ STH } & S. epidermidis & 4 \\
\hline & & & $S$. capitis & 1 \\
\hline & & \multirow[t]{2}{*}{ DEN } & $S$. epidermidis & 32 \\
\hline & & & S. haemolyticus & 1 \\
\hline & & \multirow[t]{2}{*}{ CPHL } & S. epidermidis & 5 \\
\hline & & & S. warneri & 1 \\
\hline \multirow{4}{*}{$\begin{array}{l}\text { Line-associated } \\
\text { bacteraemia }\end{array}$} & & \multirow[t]{4}{*}{ STH } & S. epidermidis & 12 \\
\hline & & & S. cohnii & 1 \\
\hline & & & S. haemolyticus & 1 \\
\hline & & & S. warneri & 2 \\
\hline
\end{tabular}

STH, St Thomas' Hospital; DEN, Denmark; CPHL, Central Public Health Laboratory, Colindale.

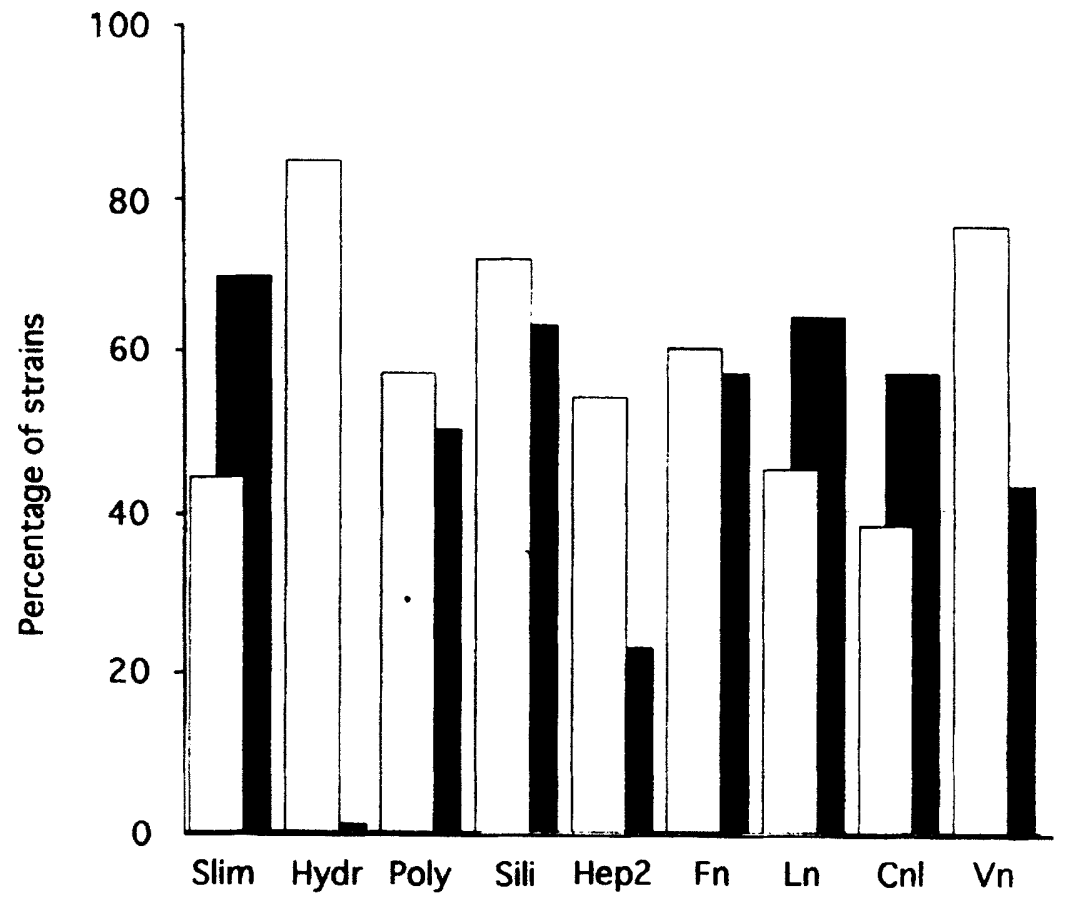

Figure. Comparison of line-associated bacteraemia strains $(\boldsymbol{\square})$ with all endocarditis strains $(\square)$.

Slim, slime production; Hydr, hydrophobicity; Poly, adherence to polystyrene; Sili, adherence to silicone; HEp2, adherence to HEp2 tissue culture cells; Fn, adherence to fibrinogen; Ln, adherence to laminin; CnI, adherence to collagen I; Vn, adherence to vitronectin.

traction of proteins with lithium chloride produced profiles with fewer bands. No differences were visible between community- and hospital-acquired strains. However, there was an additional or denser band at c. $70 \mathrm{kDa}$ in prosthetic-valve strains (data not shown). Immunoblotting of samples with antibodies raised against $S$. epidermidis and $S$. haemolyticus from CAPD was not complete. However, it appeared that community-acquired and native-valve strains were very similar to each other and different from hospitalacquired and prosthetic-valve strains (data not shown). 
Table II. Slime production, hydrophobicity and adhesion to plastics amongst CNS

\begin{tabular}{|c|c|c|c|c|c|c|c|c|}
\hline \multirow{2}{*}{$\begin{array}{l}\text { Source } \\
\text { of strains }\end{array}$} & \multicolumn{3}{|c|}{$\begin{array}{l}\text { Slime production: } \\
\text { Congo red test }(\%)\end{array}$} & \multicolumn{2}{|c|}{$\begin{array}{l}\text { Hydrophobicity: } \\
\text { salt agglutination (\%) }\end{array}$} & \multicolumn{3}{|c|}{$\begin{array}{l}\text { Adherence to } \\
\text { plastics }(\%)\end{array}$} \\
\hline & $\mathrm{n}$ & ++ & + & $\mathrm{n}$ & $\mathrm{HI}<0.25$ & $\mathrm{n}$ & Polystyrene & Silicone \\
\hline $\begin{array}{l}\text { CAE } \\
\text { HAE }\end{array}$ & $\begin{array}{l}32 \\
64\end{array}$ & $\begin{array}{l}47 \\
42\end{array}$ & $\begin{array}{l}41 \\
42\end{array}$ & $\begin{array}{l}32 \\
64\end{array}$ & $\begin{array}{l}41 \\
56\end{array}$ & $\begin{array}{l}32 \\
58\end{array}$ & $\begin{array}{l}56 \\
57\end{array}$ & $\begin{array}{l}56 \\
81\end{array}$ \\
\hline $\begin{array}{l}\text { NVE } \\
\text { PVE }\end{array}$ & $\begin{array}{l}46 \\
50\end{array}$ & $\begin{array}{l}48 \\
40\end{array}$ & $\begin{array}{l}39 \\
44\end{array}$ & $\begin{array}{l}46 \\
50\end{array}$ & $\begin{array}{l}41 \\
60\end{array}$ & $\begin{array}{l}46 \\
44\end{array}$ & $\begin{array}{l}61 \\
53\end{array}$ & $\begin{array}{l}67 \\
77\end{array}$ \\
\hline LAB & 16 & 69 & 13 & 15 & $0^{*}$ & 16 & 50 & 63 \\
\hline
\end{tabular}

CAE, community-acquired endocarditis; HAE, hospital-acquired endocarditis; NVE, native-valve endocarditis; PVE, prosthetic valve endocarditis; LAB, line-associated bacteraemia; n, number tested; HI, hydrophobicity index.

* One intermediate strain, $93 \%$ were $\mathrm{HI}>1$.

Table III. Adherence of CNS to tissue culture cells and binding to extracellular matrix proteins

\begin{tabular}{|c|c|c|c|c|c|c|c|c|c|}
\hline \multirow{2}{*}{$\begin{array}{l}\text { Source } \\
\text { of strains }\end{array}$} & \multicolumn{3}{|c|}{$\begin{array}{l}\text { Adherence to } \\
\text { HEp2 cells }(\%)\end{array}$} & \multicolumn{6}{|c|}{$\begin{array}{l}\text { Binding to extracellular } \\
\text { matrix proteins }(\%)\end{array}$} \\
\hline & $\mathrm{n}$ & positive & intermediate & $\mathrm{n}$ & Fn & $\mathrm{Lm}$ & $\mathrm{CnI}$ & $\mathbf{N}$ & $\mathrm{Vn}$ \\
\hline $\begin{array}{l}\text { CAE } \\
\text { HAE }\end{array}$ & $\begin{array}{l}31 \\
56\end{array}$ & $\begin{array}{l}61 \\
50\end{array}$ & $\begin{array}{l}16 \\
25\end{array}$ & $\begin{array}{l}32 \\
63\end{array}$ & $\begin{array}{l}72 \\
54\end{array}$ & $\begin{array}{l}69 \\
33\end{array}$ & $\begin{array}{l}38 \\
38\end{array}$ & $\begin{array}{l}5 \\
7\end{array}$ & $\begin{array}{l}60 \\
86\end{array}$ \\
\hline $\begin{array}{l}\text { NVE } \\
\text { PVE }\end{array}$ & $\begin{array}{l}45 \\
42\end{array}$ & $\begin{array}{l}60 \\
48\end{array}$ & $\begin{array}{l}22 \\
21\end{array}$ & $\begin{array}{l}46 \\
49\end{array}$ & $\begin{array}{l}59 \\
60\end{array}$ & $\begin{array}{l}54 \\
36\end{array}$ & $\begin{array}{l}28 \\
46\end{array}$ & $\begin{array}{l}7 \\
5\end{array}$ & $\begin{array}{l}71 \\
80\end{array}$ \\
\hline LAB & 14 & 23 & 0 & $14^{*}$ & 57 & 64 & 57 & 14 & 43 \\
\hline
\end{tabular}

n, number tested; CAE, community-acquired endocarditis; HAE, hospital-acquired endocarditis; NVE, native-valve endocarditis; PVE, prosthetic-valve endocarditis; LAB, line-associated bacteraemia; Fn, fibronectin; Lm, laminin; CnI, collagen I, Vn, vitronectin.

* Two strains were auto-agglutinable.

\section{Slime production, hydrophobicity and adherence}

Slime production was significantly more frequent $\left(\chi^{2}=3 \cdot 7, \mathrm{p}<0.05\right)$ amongst line-associated bacteraemia strains compared with all endocarditis strains (figure). Hydrophobicity and adherence to HEp2 cells were significantly more frequent among endocarditis strains $\left(\chi^{2}=42.8, \mathrm{p}<0.0005\right.$ and $\chi^{2}=5.1, \mathrm{p}<0.025$, respectively). However, the endocarditis strains were not homogeneous and further differences could be seen.

Community and hospital strains gave very similar results for slime production as did native- and prosthetic-valve strains (see table II). More lineassociated strains produced slime than any of the endocarditis groups and this difference was statistically significant but only for LAB versus $\operatorname{HAE}\left(\chi^{2}=3 \cdot 6\right.$, $\mathrm{p}<0.05)$ and LAB versus PVE $\left(\chi^{2}=3.4, \mathrm{p}<0.05\right)$.

Community-acquired strains were less hydrophobic than hospital-acquired strains, having a smaller percentage of strains with an $\mathrm{HI}$ value of $<0.2$ but this difference does not reach statistical significance (table II). Native-valve strains were significantly less often hydrophobic than prosthetic-valve strains $\left(\chi^{2}=4 \cdot 06\right.$, $\mathrm{p}<0.05)$. None of the line-associated strains was hydrophobic (e.g., LAB versus CAE $\chi^{2}=6.48$, $\mathrm{p}<0.025 ;$ LAB versus NVE $\chi^{2}=6.79, \mathrm{p}<0.01$ ).

\section{Adherence to plastic}

Table II shows that all the groups of organisms had very similar frequencies of adherence to polystyrene.
Experiments on adhesion to a silicone disk produced slightly different results. The organisms could be separated both by source and disease with hospitalacquired and prosthetic-valve strains adhering more frequently than the other strains, although this was statistically significant only for $\mathrm{CAE}$ versus $\mathrm{HAE}$ $\left(\chi^{2}=6.3, p<0.025\right)$.

\section{Specific adherence assays}

More community-acquired strains adhered to HEp2 cells than did hospital-acquired strains, which showed a larger percentage of intermediate adherence (see table III). This difference was also apparent between prosthetic- and native-valve strains with native-valve strains adhering to a greater extent, although the difference was less pronounced. More endocarditis strains from all groups adhered better than the lineassociated strains, reaching statistical significance for CAE versus LAB $\left(\chi^{2}=5.47, \mathrm{p}<0.025\right)$ and NVE versus $\mathrm{LAB}\left(\chi^{2}=5.5, \mathrm{p}<0.025\right)$.

In general, community-acquired strains bound fibronectin and laminin more frequently than did hospital-acquired strains, although the latter bound more frequently to vitronectin. Differences in binding between native- and prosthetic-valve strains were less pronounced whilst the binding of line-associated strains approximated to the mean of the endocarditis strains, except for poor adhesion to vitronectin. Differences that reached statistical significance were as follows: fibronectin-none; laminin-CAE versus 
HAE $\chi^{2}=10 \cdot 7, \mathrm{p}<0.005$, LAB versus HAE $\chi^{2}=4 \cdot 6$, $\mathrm{p}<0.05$; collagen type I-NVE versus PVE $\chi^{2}=3 \cdot 9$, $\mathrm{p}<0.05$. The figures for vitronectin were too small to reach statistical significance.

\section{Discussion}

The staphylococcal species and antibiograms were broadly those anticipated from published studies ${ }^{21}$ with more antibiotic resistance being seen amongst the hospital strains. Relatively few strains possessed plasmids and those that did had no common band that might have been related to adherence. This agrees with previous studies that indicated a high percentage of plasmid-bearing strains amongst patients with prosthetic-valve endocarditis although no common patterns have appeared. ${ }^{22-24}$ Although an adherence plasmid has been described in staphylococci, ${ }^{25}$ this has not been confirmed. In this series, plasmid carriage was more common in strains from Denmark but this may simply reflect the current epidemiology of strains there.

Whole-cell protein patterns were species specific, agreeing with published reports. ${ }^{26}$ Immunoblotting with rabbit antisera also indicated differences between the groups of strains. Cell-surface protein profiles, which, with fewer bands, were easier to analyse, indicated that a $70-\mathrm{kDa}$ band was present in prosthetic-valve strains which was absent or reduced in native-valve strains. A protein band of this size has been associated with binding to vitronectin in $S$. aureus $^{27}$ but, in this series of CNS strains, binding was fairly evenly distributed amongst prosthetic- and native-valve strains.

The reference coagulase-positive and coagulasenegative strains were used to define positive and negative responses as described by ourselves and others. ${ }^{8.28-30}$

The ability to adhere to host tissue or prostheses is a prerequisite for infection. Several in-vitro measures of adherence have been proposed and these can be divided into the specific and non-specific. Specific methods include adherence to tissue culture cells and binding to extracellular matrix proteins, whilst the non-specific methods range from production of a glycocalyx, "slime", through hydrophobicity to adherence to laboratory plastics. The ability of CNS to produce slime was first described by Bayston and Penny ${ }^{31}$ and was later associated specifically with adherence to intravenous catheters and prostheses. In recent years it has become evident that a high percentage of CNS isolates from catheters are characterised phenotypically by the ability to produce slime ${ }^{32}$ but the chief problem has been the absence of an efficient method of assay. Culture on Congo red agar was relatively easy to read objectively and was more reproducible. However, the results were paradoxical in that more native-valve strains produced slime than did prosthetic-valve strains, although pro- portionately fewer than in line-associated strains, suggesting that slime production may have more than one function in endocarditis. The importance of slime production in vivo is difficult to determine, but the ability of $S$. epidermidis strains to produce slime in vitro was not found to affect the outcome of vancomycin treatment in an experimental catheterinduced endocarditis in rabbits. ${ }^{33}$

The evidence suggesting that hydrophobicity is important in the adherence of CNS is not conclusive and different measurements of hydrophobicity may give conflicting results. ${ }^{34}$ Nevertheless, it is curious that although about half of the endocarditis strains were hydrophobic, all of the line-associated strains were hydrophilic, a result that must reflect differences in their cell-wall structure.

Adherence to plastics has the merit of being easy to measure objectively by spectrophotometry ${ }^{13}$ although appropriate plastics are rarely used. In this study, adherence to polystyrene and to silicone rubber, as used in catheter manufacture, were similar but not identical. Adherence to silicone was significantly greater for hospital- than community-acquired strains, whilst on polystyrene adherence was equal. Published studies have shown that adherence of CNS to catheters in vivo is associated with the presence of micro-colonies embedded in an amorphous substrate. ${ }^{35}$ It is worth noting that catheters and prostheses in situ rapidly become coated with plasma proteins, so that adherence and micro-colony formation in vivo may be related to adherence to extracellular proteins as well as adherence to plastics per se. ${ }^{29,36}$

Tissue culture cells offer a more realistic model for adherence, although ideally the cells available should be of the same type as the original host cells. In the study reported here, the human epithelial cell line, HEp2, clearly separated the endocarditis strains from the line-associated strains. Furthermore, more community-acquired and native-valve strains adhered well than did hospital-acquired and prosthetic-valve strains although the differences were not significant. In a study of $S$. aureus binding to porcine cardiac valve cells $^{37}$ it was found that binding to endothelial and subendothelial cells was mediated by different proteins; for subendothelial cells, this protein was most probably fibronectin.

Fibronectin and vitronectin are present in plasma and on cell surfaces, whereas laminin is an intrinsic component of basement membranes, the extracellular matrices found at the boundary between cells and connective tissue, but these proteins, together with fibrinogen, may act in vitro as adhesins for CNS on catheters. ${ }^{29}$ The extracellular matrix protein binding assay used in this study has been shown to be highly reproducible and reliable,$^{15}$ although the results generated were complex. The community-acquired strains were more likely to bind to laminin than were hospital-acquired strains, but the reverse was true for vitronectin. In traumatised tissues, basement membrane proteins are exposed ${ }^{38}$ as would occur during 
non-bacterial thrombotic endocarditis and it may account for the selection of strains with lamininbinding ability in CAE and NVE. Adherence of the endocarditis strains to collagen type I was comparatively poor, but since this protein is a major component of connective tissue in skin, bone and tendon, it is less likely to exert a selective influence on organisms in the bloodstream.

In conclusion, this study has revealed some differences between strains of staphylococci isolated from cases of endocarditis and those from intravenous line-associated bacteraemias. Endocarditis strains were found to be more likely to adhere to tissue culture cells, were more often hydrophobic, and were less likely to produce slime than line-associated strains. Endocarditis strains from prosthetic-valve or hospital-

\section{References}

1. Baddour LM. Twelve-year review of recurrent native-valve infective endocarditis: a disease of the modern antibiotic era. Rev Infect Dis 1988; 10: 1163-1170.

2. Schmidt BK, Kirpalani HM, Corey M, Low DE, Philip AGS, Ford-Jones EL. Coagulase-negative staphylococci as true pathogens in newborn infants: a cohort study. Pediatr Infect Dis $J$ 1988; 6: 1026-1031.

3. Patrick CC. Coagulase-negative staphylococci: pathogens with increasing clinical significance. $J$ Pediatr 1990; 116: 497-507.

4. Fidalgo S, Vázquez F, Mendoza MC, Pérez F, Méndez FJ. Bacteraemia due to Staphylococcus epidermidis: microbiologic, epidemiologic, clinical, and prognostic features. Rev Infect Dis 1990; 12: 520-528.

5. Baltimore RS. Infective endocarditis in children. Pediatr Infect Dis $J$ 1992; 11: 907-912.

6. Wilson CR, Totten PA, Baldwin JN. Rapid procedure for the detection of plasmids in Staphylococcus epidermidis. Appl Environ Microbiol 1978; 36: 368-374.

7. Pierre J, Gutmann L, Bornet M, Bergogne-Berezin E, Williamson $R$. Identification of coagulase-negative staphylococci by electrophoretic profile of total proteins and analysis of penicillin-binding proteins. J Clin Microbiol $1990 ; 28: 443-446$.

8. Paulsson $M$, Petersson A-C, Ljungh $\AA$. Serum and tissue protein binding and cell surface properties of Staphylococcus lugdunensis. J Med Microbiol 1993; 38: 96-102.

9. Dryden MS, Talsania HG, Martin S et al. Evaluation of methods for typing coagulase-negative staphylococci. $J$ Med Microbiol 1992; 37: 109-117.

10. Lindahl M, Faris A, Wadström T, Hjertén S. A new test based on "salting out" to measure relative surface hydrophobicity of bacterial cells. Biochim Biophys Acta $1981 ; 677: 471-476$.

11. Ljungh $\AA$, Hjertén $S$, Wadström T. High surface hydrophobicity of autoagglutinating Staphylococcus aureus strains isolated from human infections studied with the salt aggregation test. Infect Immun 1985; 47: 522-526.

12. Freeman DJ, Falkiner FR, Keane CT. New method for detecting slime production by coagulase negative staphylococci. J Clin Pathol 1989; 42: 872-874.

13. Christensen GD, Simpson WA, Younger JJ et al. Adherence of coagulase-negative staphylococci to plastic tissue culture plates: a quantitative model for the adherence of staphylococci to medical devices. J Clin Microbiol 1985; 22: $996-1006$

14. Wilcox MH, Finch RG, Smith DG, Williams P, Denyer SP. Effects of carbon dioxide and sub-lethal levels of antibiotics on adherence of coagulase-negative staphylococci to polystyrene and silicone rubber. J Antimicrob Chemother 1991 ; 27: 577-587.

15. Naidu AS, Paulsson M, Wadström T. Particle agglutination acquired disease were more likely to be hydrophobic and to adhere to silicone than were native-valve or community-acquired strains. Adherence to HEp2 tissue culture cells and binding to fibronectin and laminin were more common in strains from native-valve or community-acquired infections and may reflect selective adherence to exposed basement membrane proteins in damaged heart tissue before clinically apparent infective endocarditis.

This study was supported by the British Heart Foundation to whom we are grateful. We are indebted to $\mathbf{H}$. Talsania, Department of Microbiology, St Thomas' Hospital, for the gift of sera and to Dr J. Reuther for HEp2 cells. We thank Professor T. Wadström (Lund University, Sweden) and his staff for their help and the gift of assay materials for extracellular matrix proteins; and Drs S. Eykyn, J. Richardson and V. T. Rosdahl for the gift of strains.

assays for rapid detection of fibronectin, fibrinogen, and collagen receptors on Staphylococcus aureus. $J$ Clin Microbiol 1988; 26: 1549-1554.

16. Cree RGA, Aleljung $\mathrm{P}$, Paulsson $\mathrm{M}$ et al. Cell surface hydrophobicity and adherence to extracellular matrix proteins in two collections of methicillin-resistant Staphylococcus aureus. Epidemiol Infect 1993; 112: 307-314.

17. Cree RGA. Investigation of the adherence properties of staphylococci. PhD Thesis, University of London. 1993.

18. Vuento M, Vaheri A. Purification of fibronectin from human plasma by affinity chromatography under non-denaturing conditions. Biochem J 1979; 183: 331-337.

19. Valkonen KH, Veljola A, Dagberg B, Uhlin BE. Binding of basement-membrane laminin by Escherichia coli. Mol Microbiol 1991; 5: 2133-2141.

20. Yatohgo T, Izumi $M$, Kashiwagi $H$, Hayashi $M$. Novel purification of vitronectin from human plasma by heparin affinity chromatography. Cell Struct Funct 1988; 13: 281-292.

21. Etienne $\mathbf{J}$, Eykyn SJ. Increase in native valve endocarditis caused by coagulase negative staphylococci: an AngloFrench clinical and microbiological study. $\mathrm{Br}$ Heart $\mathrm{J}$ 1990; 64: 381-384.

22. Etienne J, Brun Y, El Solh N et al. Characterization of clinically significant isolates of Staphylococcus epidermidis from patients with endocarditis. J Clin Microbiol 1988; 26: 613-617.

23. Birnbaum D, Kelly M, Chow AW. Epidemiologic typing systems for coagulase-negative staphylococci. Infect Control Hosp Epidemiol 1991; 12: 319-326.

24. Archer GL, Vishniavsky N, Stiver HG. Plasmid pattern analysis of Staphylococcus epidermidis isolates from patients with prosthetic valve endocarditis. Infect Immun 1982; 35: $627-632$.

25. Dunkle LM, Blair LL, Fortune KP. Transformation of a plasmid encoding an adhesin of Staphylococcus aureus into a non-adherent staphylococcal strain. J Infect Dis 1986; 153: $670-675$.

26. Plaunt MR, Patrick CC. Identification of the innate human immune response to surface-exposed proteins of coagulasenegative staphylococci. J Clin Microbiol 1991; 29 : 857-861.

27. Paulsson M, Liang OD, Ascencio F, Wadström T. Vitronectinbinding surface properties of Staphylococcus aureus. Int J Med Microbiol Virol Parasitol Infect Dis 1992; 277 : 54-64.

28. Wadström T, Paulsson M, Ljungh A. Molecular pathogenesis of staphylococcal infections: microbial adhesion to extracellular matrix and colonization of wounded tissues and biomaterial surface. In: Möllby R, Flock J-I, Nord CE et al. (eds) Staphylococci and staphylococcal infection. Zentralbl Bakteriol Suppl 26 1994: 343-352.

29. Herrmann M, Vaudaux PE, Pittet D et al. Fibronectin, fibrinogen, and laminin act as mediators of adherence of clinical staphylococcal isolates to foreign material. $J$ Infect Dis 1988; 158: 693-701. 
30. Wyatt JE, Poston SM, Noble WC. Adherence of Staphylococcus aureus to cell monolayers, J Appl Bacteriol 1990; 69: $834-844$.

31. Bayston R, Penny SR. Excessive production of mucoid substance in staphylococcus SIIA: a possible factor in colonisation of Holter shunts. Dev Med Child Neurol 1972; 27 Suppl: 25-28.

32. Dunne WM, Burd EM. Fibronectin and proteolytic fragments of fibronectin interfere with the adhesion of Staphylococcus epidermidis to plastic. $J$ Appl Bacteriol 1993; 74: 411-416.

33. Steckelberg JM, Keating MR, Rouse MS, Wilson WR. Lack of extracellular slime effect on treatment outcome of Staphylococcus epidermidis experimental endocarditis. $J$ Antimicrob Chemother 1989; 23 : 117-121.

34. Hjertén $S$, Wadström $T$. What types of bonds are responsible for the adhesion of bacteria and viruses to native and artificial surfaces? In: Wadström T, Eliasson I, Holder I et al. (eds) Pathogenesis of wound and biomaterialassociated infections. London, Springer Verlag. 1990: 245-253.

35. Peters G, Locci R, Pulverer G. Microbial colonization of prosthetic devices. II. Scanning electron microscopy of naturally infected intravenous catheters. Zentralbl Bakteriol Mikrobiol Hyg B 1981; 173: 293-299.

36. Timmerman CP, Fleer A, Besnier JM, De Graff L, Cremers F Verhoef J. Characterization of a proteinaceous adhesin of Staphylococcus epidermidis which mediates attachment to polystyrene. Infect Immun 1991; 59: 4187-4192.

37. Campbell KM, Johnson CM. Identification of Staphylococcus aureus binding proteins on isolated porcine cardiac valve cells. J Lab Clin Med 1990; 115: 217-223.

38. Proctor RA, Mosher DF, Olbrantz PJ. Fibronectin binding to Staphylococcus aureus. J Biol Chem 1982; 257: 14788-14794. 